\title{
Language in the Provincial Capital Public Space in the Perspective of Local Wisdom
}

\author{
S Ladyanna ${ }^{1}$, R Almos ${ }^{2}$ \\ $\left\{{ }^{1}\right.$ sonezzaladyanna@hum.unand.ac.id, ${ }^{2}$ ronaalmos@hum.unand.ac.id $\}$ \\ ${ }^{1,2}$ Universitas Andalas, Padang, Indonesia
}

\begin{abstract}
The language used in public spaces in the provincial capital is the first form of communication that is immediately visible to the public. Language in public space must be accepted by society in general and perspective on local wisdom. Therefore, in this article, it is explained about the use of language in the provincial capital's public space and analysis of the perspective of local wisdom in the language used. This research is a qualitative research with pragmatic and anthropolinguistic analysis. The source of this research data is written language used in the public space of the capital of West Sumatra Province. Then, the data is analyzed in the framework of sociopragmatic and anthropolinguistic studies. From the analysis, it can be concluded that the language used in the public space of the provincial capital consists of regional languages, Indonesian, and foreign languages. The type of speech acts used are direct and indirect speech acts with locutionary, illocutionary, and perlocutionary effects. The use of this form of language is an image of the local wisdom of the Minangkabau people as residents of the majority of the provincial capital.
\end{abstract}

Keywords: Language, Public Spaces, Local Wisdom

\section{INTRODUCTION}

The language used in public spaces in the provincial capital is the first form of communication that is immediately visible to the public. Public space is also a place for social interaction [1]. Language in public space should be easily understood by the public in general and to perspective the local wisdom of the community.

One place of communication in the public space that is intended for many people is public service advertising. Public service advertisements are a place to convey notifications, appeals, or prohibitions to the public. Supposedly, public service advertising is delivered as effectively as possible by paying attention to the use of language that is in accordance with the character of the community. For this reason, the attention of linguists is needed regarding the use of language in public service advertisements.

From numbers of studies on public service announcements, not many have focused research on the use of language in the perspective of local wisdom. [2] Ladyanna (2008) has conducted research on public service announcements in the city of Padang. Ladyanna examines the use of language from the sociopragmatic review. Research on public service announcements is mostly carried out from the perspective of communication science and semiotics, as conducted by the following researchers. [3] Atkin (2001) conducted a study of appropriate strategies for making public service announcements about health more effective. From his research, it can be concluded that the selection of advertising media must be adjusted to the appeal submitted. [4] Emilkamayana (2013) conducted a study on the effect of public 
service announcements on the Ministry of Health of the Republic of Indonesia of AntiSmoking on smoking behavior in Sempaja Selatan Village, North Samarinda District. Emilkamayana stated that there was no effect of anti-smoking public service advertisements on smoking behavior because the advertising variables did not significantly influence smoking behavior in the community.

Yunita, Anggraini, Condra Antoni, and Sandi Prasetyaningsih (2018)-[5] conducted research on motion graphics technology in creating animated public service announcements and delivering messages of the dangers of smoking using Pierce's semiotics. From the results of his research, it can be concluded that icons, indexes and symbols have certain functions in these advertisements. Tinarbuko (2016)- [6] also conducts research on public service advertisements with semiotic analysis because the mastery of the theory of visual communication semiotics is considered very important in expanding imagination and insight in the process of creating advertisements.

Public service advertisements in the provincial capital of West Sumatra are very interesting to study because they have unique characteristics regarding the local wisdom of the Minangkabau people as a minority community in this city. One of them is reflected in the inclusion of the theme of Islamic teachings in the ad without causing controversy in the community. These service advertisements are present without causing multicultural conflict and debate.

Therefore, in this article, it is explained about the use of language in the provincial capital's public space and analysis of the perspective of local wisdom in the language used. The discussion in this article is expected to be used by policy makers in presenting messages to the public through qualified public service advertisements. Thus, the use of language in the public space is becoming more effective.

\section{RESEARCH METHOD}

This research is a qualitative research with sociopragmatic and anthropolinguistic analysis. The data source of this research is written language used in the public space of the capital of West Sumatra Province, especially written language on public service advertisements issued by government agencies. The location of the data source is determined based on the place that is visited by the general public such as the main road and tourist attractions. In addition, it is also considered an area that has a lot of service advertisements and commercial advertisements because the place is certainly an area that is visited by or passed by the community so that it becomes a strategic place to convey information.

Then, the data is analyzed in the framework of sociopragmatic and anthropolinguistic studies. Sociopragmatics is an interdisciplinary study between sociolinguistics and pragmatics. Sociopragmatic studies are used to examine the pragmatics of speech that arise due to the influence of the social context of the community so that the social aspects will determine the hidden meaning of speech [7]. Anthropolinguistics is a study of language as a cultural resource and speech as a cultural practice [8]. So, the culture stored in the human mind as shared knowledge serves to explain the meaning of speech as a cultural practice. Palmer stated that anthropolinguistics is a name that tends to contain broad understanding in terms of language and culture [9]. 


\section{RESULTS AND DISCUSSION}

The display of language usually transmits symbolic message as to the legitimacy, relevance, priority and standards of languages and the people they represent [10]. Language modelling approaches to information retrieval are attractive and promising because they connect the problem of retrieval with that of language model estimation [11].The use of language in the public space of the provincial capital in Indonesia varies because it is found in the use of regional languages, Indonesian, and foreign languages. The forms of speech acts are also variously used, namely direct and indirect speech acts with locutionary, illocutionary, and perlocutionary effects. Here's the full exposure.

The following community service advertisements can be found on several main roads in Padang City, the capital of West Sumatra Province. This advertising can be seen easily because of its large size and strategic position. The advertisement is equipped with a silhouette of female illustrations.

"Pesan istri kepada suami: "Wahai suamiku carilah rezeki yang halal saja. Aku dan anak-anakmu rela lapar dengan sedikit tapi halal, daripada kenyang namun dibakar api neraka"

"The wife's message to her husband:" O my dear husband, seek legal sustenance. My children and I are willing to be hungry with a little but halal, rather than full but burnt by the fire of hell."

The language used in the public service advertisement is Indonesian so that it can be easily understood by the Indonesian people. The type of speech act used is indirect speech acts. Indirect speech acts, namely if the news sentence and question sentence are used to order or use a sentence that is not in accordance with its conventional function [12]. In these public service advertisements, news sentences are used to govern. So, the advertising maker rules or invites the public to follow the message delivered. The message contains teachings to seek halal sustenance in accordance with religious teachings.

The majority of people in the capital city of the province are Minangkabau culture with Islamic background according to the Minangkabau traditional philosophy "adat basandi syarak, syarak basandi kitabullah" which has the intention that adat is based on the teachings of Islam. In this religious teaching, the husband is the head of the family who is obliged to make a living for his wife and child in a halal manner. If the sustenance is not obtained lawfully, the family will enter hell.

Speech acts in public service advertisements contain locutionary, illocutionary, and perlocutionary effects. Locutionary is a speech to express something, illocutionary is a speech act which in addition functions to say something, also to do something, and perlokusi is a speech act that has perlocutionary force or effect (Searle dalam [12]). The locution of the speech act in the advertisement is to express the wife's message to the husband to seek halal sustenance so that they avoid the torment of hellfire. Meanwhile, the illocutionary of the utterance is to order or invite the public to seek halal sustenance. The speech act also contains perlocutionary which is to influence the community to seek halal sustenance in order to avoid hell.

These community service advertisements are colored by the teachings of Islam in accordance with the religion and culture of the community. So, the local wisdom of the people in the city is imaged by the contents of the advertisement. Likewise in the following adverts. 
“Himbauan Pemerintah Kota Padang Tahun Baru, daripada "Om telolet Om” lebih baik "Om shalawat Om! Mari ramaikan mesjid/mushalla terdekat dengan zikir dan muhasabah"

"The appeal of the City Government of Padang in the New Year, rather than "Om Telolet Om" is better "Om Salawat Om! Let's enliven the mosque / mushalla closest to zikir and muhasabah"

The advertisement uses speech in Indonesian. So, that it can be understood by Indonesianspeaking people only because it is intended primarily to appeal to the local community. When this advertisement is released, local people, especially young people, are having a habit or trend to ask a large vehicle driver (such as a truck or bus) who has a horn with a high tone to sound the horn with a rhythm that has a sound like the word "telolet". This habit brings pleasure to them, but can threaten road safety because this activity is carried out on the edge of the highway when the vehicle is passing.

The situation is used by the government to give an invitation in accordance with the teachings of Islam by using direct speech acts because the command sentence is used according to its function, namely to govern. However, the speech still uses comparisons with trends in the community. Speech actions in these advertisements contain localization and perlocutionary. The locus is in accordance with the contents of the advertisement, namely inviting the public to ask drivers to pray because the prayer is better. In addition, also invites people to enliven the place of worship with activities in accordance with religious teachings. Perlocutionary in the advertisement is to influence the community to do what they say.

These advertisements are still in the atmosphere of religion such as the local wisdom of the Minangkabau people who have religious beliefs. Furthermore, the following public service advertisements are different from advertisements before because they do not invite the public to seek halal sustenance or make zikir, but invites the public to comply with traffic regulations.

\section{“Dilarang Ngebut Penggali Kubur sudah Mudik Lebaran”}

"It is forbidden for speeding, the diggers to bury already homecoming for Eid"

In the advertisement, the community was prohibited from speeding (driving vehicles at high speed) because the grave diggers had returned home to celebrate Eid al-Fitr. The advertisement was released ahead of the Idul Fitri celebration. Driving a vehicle at high speed will result in an accident and can cause death. In accordance with the religious teachings of the majority of the population in this region, namely Islam, the corpse must be buried in the ground. To dig a grave, of course it requires a grave digger, however, the grave digger is not there because of returning home to celebrate the feast.

The contents of the advertising contain irony jokes. The government conveyed the message as interestingly as possible so that the community was interested and finally moved to follow the message. Death in Islam has a rule that the body must be buried before 24 hours and the community is very concerned about it. Speech acts in service advertisements use Indonesian with direct speech. The speech contains the power of localization which is to forbid people of road users to drive vehicles with high speed and perocutionary which is to influence the community to follow what is conveyed. 
In addition to the use of Indonesian, public service advertisements also use regional languages and foreign languages, especially English, as in the following data.

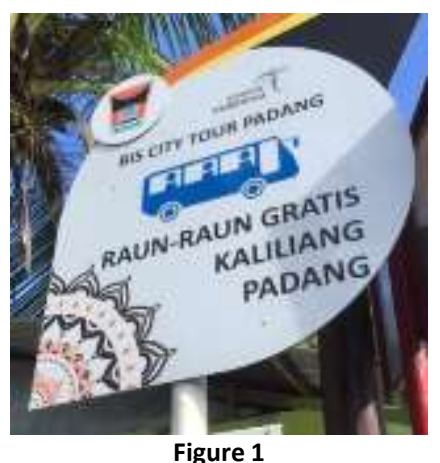

In these advertisements, several languages are used, namely Indonesian in the word "gratis" which means unpaid services. Then, also used regional languages namely Minangkabau language in "raun-raun" which means travelling and on "kaliliang" which means around. After that, a foreign language is also used, namely English at the beginning of the "city tour bus" which means the bus for sightseeing trips in the city.

The use of Indonesian and English aims to facilitate the communication process with opponents. This advertisement is an advertisement released by the Tourism Office in order to inform tourism supporting facilities for visitors who are not only local residents but also domestic and foreign tourists. The use of the Minangkabau language is one step in maintaining regional languages so that the public or visitors also know the local language. It portrays the local wisdom of Minangkabau people who indeed still have to uphold customs in millennial times.

Public service advertisements that contain appeals or encouragement and bans in the public space of the provincial capital of West Sumatra reflect the local wisdom of the Minangkabau community as a majority community. Minangkabau people have local wisdom to use figures of speech or comparisons or indirect speeches in appealing or inviting or prohibiting or pointing out teaching in social problems [13]. So, the use of indirect speech acts with illocutionary power or perlocutionary for announcements or appeals and prohibitions in public service advertisements in the public space is a form of speech that is in accordance with the characteristics of the Minangkabau community.

The contents of the invitation or appeal and prohibitions relating to the teachings of Islam are also in accordance with the local wisdom of the Minangkabau people. Minangkabau society is a society that makes the Qur'an (the holy book adhering to Islam) as a source of life value, the Minangkabau community places the mind as the determinant of value based on to the value of goodness, and evil, and the values of life are a reflection of personal values and cultural values that are connected cooperatively, interpretive, and dynamic [14].

In addition, advertising content must also follow the trend of the community at the time so that the message community is delivered faster and on target. Moreover, if the target object of the public service ad is the younger generation, the ad content must touch the trend that is trending among them. This will make the target feel that the ad is theirs so that interest will turn into a paradigm that can change their concept of thinking. This thought has been started by the Padang City Government as the maker of public service advertisements that appeared 
in one of the advertisements that used the "om, telolet om" trend. Troiano research about the Angelina Joelie effect-impact on breast and ovarian cancer prevention and the results are celebrity disclosures can influence patient's behaviour leading to important effects on attitudes tiwards screening [15].

Thus, public service advertisements in the provincial capital of West Sumatra reflect the local wisdom of the Minangkabau cultural community. The Minangkabau cultural community is the majority community in this region. Service advertising that are in accordance with the character of the community will not trigger controversy, but will be a reminder for people who read it. So, good public service advertisements are public service advertisements that are in accordance with the character of the target community and reflect the local wisdom of the people in the region.

In addition, public service advertisements in the provincial capital's public spaces have also thought of a trending trend in young people. This trend is used to propagate the local wisdom of the Minangkabau cultural community. Carrying the concept of local wisdom must indeed be supported by a mass culture that develops in various circles of society so that propaganda in these advertisements can touch every level of society [16].

\section{CONCLUSIONS}

It can be concluded that the language used in the public space of the provincial capital consists of regional languages, Indonesian, and foreign languages. The types of speech acts used are direct and indirect speech acts with locutionary, illocutionary, and perlocutionary effects. The use of these forms of language is an image of the local wisdom of the Minangkabau people as the majority citizens of the provincial capital. Public service advertisements that are in accordance with the character of the target community and reflect local wisdom are good and qualified advertisements. In addition, public service advertisements must also consider the mass culture that develops in various circles of society so that propaganda in these advertisements can touch every level of society.

\section{REFFERENCES}

[1] K. Peters and A. Buijs, "Social interactions in urban parks:Stimulating social cohesion?," Urban For. Urban Green., vol. 9, no. 2, pp. 93-100, 2010.

[2] S. Ladyanna, "Iklan Layanan Masyarakat di Kota Padang Tinjauan Sosiopragmatik," Gajah Mada, 2008.

[3] Atkin Charles, "Impact pf Public Service Adverticing Research Avidence and Effective strategies," 2001.

[4] Emilkamayan, "Pengaruh Iklan Layanan Masyarakat Kemetrian Kesehatan RI Anti Rokok terhadap Perilaku Merokok di Kelurahan Sempaja Selakan Kaecamatan Samarinda Utara," Ilmu Komun., vol. 1, no. 2, 2013.

[5] Y. Anggarini, C. Antoni, and S. Prasetyaningsih, "Analisis dan Implementasi Motion Garfis Iklan Layanan Masyarakat (ILM) dengan Metode semiotik Peirce," Ekspresi Persepsi, vol. 1, no. 1, 2018.

[6] S. Tinarbuko, "Semiotika Tanda Verbal dan Tanda Visual Layanan Masyarakat," Seni Budaya Panggung, vol. 26, no. 2, 2016.

[7] Jonathan Culpeper (ed.), Historical Sociopragmatics. Netherlands: John Benjamins Publishing, 2011.

[8] A. Duranti, Linguistic Antropology. Cambridge: Cambridge University Press, 1997. 
[9] G. B. Palmer, Toward A Theory of Cultural Linguistics. Austin: University of Texas Press, 1996.

[10] L. Zhang and L. Tsung, "Language Used in Public Spaces," Springer, Cham, 2019, pp. 113-147.

[11] C. Zhai and J. Lafferty, "A Study of Smoothing Methods for Language Models Applied to Ad Hoc Information Retrieval," ACM SIGIR Forum, vol. 51, no. 2, pp. 268-276, Aug. 2017.

[12] I. D. P. Wijana, Dasar-Dasar Pragmatik. Yogyakarta: Andi, 1996.

[13] Hasanuddin-WS, "The Intangible Cultural Heritage of Minangkabau Traditional Expressions: The Local of The Society in Advising and Noble Advicing," Ilmu-Ilmu Hum., vol. 2, pp. 131-141, 2016.

[14] M. Munir, M. Glorino, and R. Pandin, "The Local Genius Values of Minangkabau Society," in Proceedings of the International Conference of Communication Science Research, 2018.

[15] G. Troiano, N. Nante, and M. Cozzolino, "The Angelina Jolie effect - Impact on breast and ovarian cancer prevention A systematic review of effects after the public announcement in May 2013," Health Educ. J., vol. 76, no. 6, pp. 707-715, Oct. 2017.

[16] K. Saddhono, "Language of Coastal Communities in the Northern Coast of Central Java: Sociolinguistic Studies in Cultural Integration Maritime-Agrarian Perspective." Adv. Sci. Let. vol. 23 no. 10 pp 10054-10056, 2017 